\title{
Microfinance Intervention and Livelihood Status: A Case of Gramin Bikash Bank Limited
}

\author{
Ramkrishna Chapagain ${ }^{1}$ \\ Rishikesh Aryal ${ }^{2}$
}

\begin{abstract}
This paper attempts to focus on the impact of micro finance intervention on livelihood status of the people taking samples of 60 respondents of microfinance intervened and 60 non intervened population of Grameen Bikash Bank which lies on remote area of Pokhara, Leknath Metropolitan city and nearby VDCs. The study is based on the randomized control trial approach and data were collected through researcher administered questionnaire. Respondents were taken through stratified sampling. The research finds that microfinance intervention has association with occupational status, micro enterprise creation, frequency of loan taken and occupational change. Independent sample t-test shows micro finance intervention increases income level, capital expenditure, consumption expenditure and saving. The regression analysis shows that micro finance intervention changes the livelihood status of women of rural areas of Pokhara Municipality and nearby VDCs.
\end{abstract}

Key words: microfinance, intervention, non- intervention, remote, income level, capital expenditure, occupational status, consumption expenditure, information access, livelihood status.

\section{Introduction}

Microfinance is the term that has come to refer generally to such informal and formal arrangements offering financial services to the poor. Microfinance has existed, although mostly in the shadows and unseen by casual observers, since the rise of formal financial systems, and indeed probably predates them. It has only been within the last four decades, however, that serious global efforts have been made to formalize financial service provision to the poor. This process began in earnest around the early to mid-1980s and has since gathered an impressive momentum. Today there are thousands of MFIs providing financial services to an estimated 100 - 200 million of the world's poor (Christenet al., 1995).

In context of Nepal,first attempt of cooperative activities in Chitwan district in 1956 can be distinguished as a primary set of microfinance. It was in use by registering first cooperative "Bakhan Singh Credit" in Rapti doon of Chitwan, mainly focusing on shelter. Cooperative bank for investing cooperates was established in 1963AD.

Nepal Grameen Bikas Bank Ltd. (NGBBL) came into existence in 2014 August 15 (Shrawan 30, 2071) with the successful merger of the then five regional level Grameen Bikas Bank operated in the five development region of Nepal. The NGBBL was registered as a public limited company on 30th July 2014 (Shrawan 14, 2071) under Company Act, 2063 and is regulated under Bank and Financial Institution Act, 2063. As a national level micro

1 Mr. Chapagain is lecturer at School of Business, Pokhara University, Email: ramkrishnachapagain@gmail.com

2 Mr. Aryal was MBA student, School of Business, Pokhara University 
finance development bank, the bank has been working continuously with the prime objective of alleviating poverty, hardship and suffering of the rural people throughout its working area by providing them micro finance services. The unique traits of the bank are well defined target group (especially women), area approach, group guarantee lending, non collateral lending etc.In order to achieve its goal, the bank has been working through micro credit services and capacity development program for the community. Moreover, it has followed the Grameen Bank Model started by Prof. Muhammad Yunus (Nobel Laureate) in Bangladesh.

It must be emphasized too that the animating motivation behind the microfinance movement was poverty alleviation. Not only that, but microfinance offered the potential to alleviate poverty while paying for it and perhaps even turning a profit doing well by doing well. This potential, perhaps more than anything, accounts for the emergence of microfinance onto the global stage (Woller, 2004). Microfinance involves the provision of financial services such as savings, loans and insurance to poor people living in both urban and rural settings who are unable to obtain such services from the formal financial sector (UNDP, 2005). The livelihood of women in the rural areas of Nepal is difficult, because either of social problems like superstitious beliefs, domestic violence and illiteracy or other problems like lack of drinking water, fodder and firewood. Male dominance and non-inclusion of women in family or community decision making have created a situation in which women of rural Nepal are living their lives in misery. This situation then calls for women to stand up together for themselves and to make a participatory effort to destroy the foundations of the patriarchal society. This has already begun since the last few decades and the collaborative effort from the name of Self Help Groups (SHGs) has proved successful in several areas like community management, gender equality and eradicating social evils. An example of a success is the community forest management with women's group (Agrawal, 2009).

The aim of MFIs as development organisations is to render financial and non-financial services to the people that ultimately help to transform their socio-economic status. These development objectives generally include (i) reducing poverty, (ii) to empower women or other disadvantaged population groups, (iii) to create employment, and (iv) encouraging for micro-business or enterprises creation. The clients need different kinds of services to solve a wide range of financial problems at different points in time. The figure 1.1 depicts the typical financial needs that can be fulfilled through micro-finance services for the people who have no capacity to take loans from formal financial institutions (Helms, 2006).

Fig. 1.1: Financial Needs Fulfilled through Micro-Finance Services

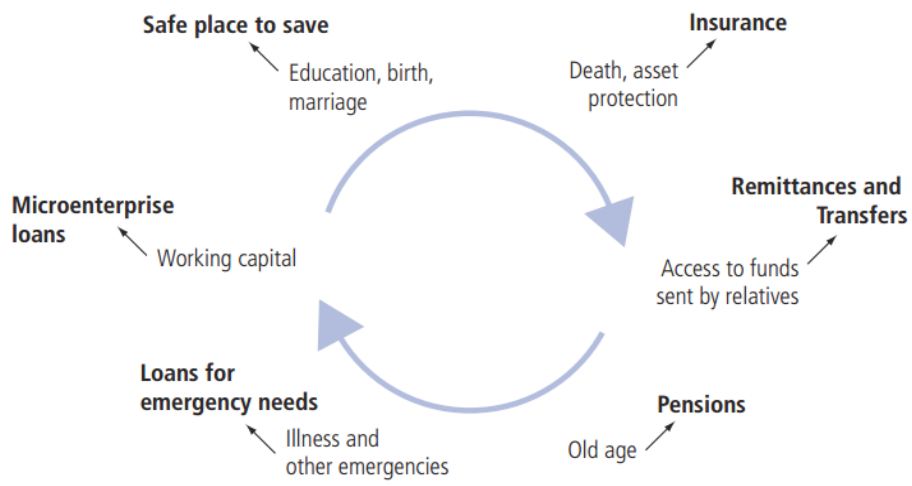

Source: CGAP, Access for All: Building Inclusive Financial Systems, pp. 23. 


\section{Objectives of the study}

The main objective of this study was how microfinance intervention changes the livelihood status of people. Other specific objectives were identifying the demographic profile of both micro finance intervened and micro finance non intervened groups, impact of microfinance intervention on income, consumption expenditure capital expenditure saving and information awareness.

\section{Literature Review}

Ayodeji, Adesola \& Fisayo (2015) in their article, Microfinance Banks and Socio-economic Development of Lagos State, adopted a survey research design, and data collected were analyzed using chi- square technique. This research reveals that in spite of all the images microfinance banks have always portrayed, in Nigeria, the situation on ground appears to be different, and as the role played by microfinance banks in the socio- economic development of Lagos State is insignificant.

George \& Kumar (2014) in their article entitle "Micro Finance for Socio-Economic Empowerment of Women - A Study of Stree Shakti Programme in the State of Karnataka" concluded that women must be empowered by enhancing their awareness, knowledge; skills and technology use efficiency, thereby, facilitating overall development of the society. The concept of Self Help Groups (SHGs) is proving to be a helpful instrument for the empowerment of women. Therefore an attempt is made in this paper to find out the performance and appraisal of the Microfinance through Stree Shakthi programme in Karnataka. This paper observes how SHGs of the rural poor particularly those managed by women, successfully demonstrated how to mobilize and manage thrift activities, appraise credit needs, enforce financial disciplines, maintain credit linkage with banks and effectively undertake income generating activities.

Ray (2008) stated that, energy for development may lie within the SHGs of poor rural women; it has to be complemented by broader sets of ideas and organizations. In his article "Alleviating Poverty through Micro-finance: SGSY Experience in Orissa", the socio-economic, political and even geographical contexts of groups and external linkages, which may operate through state and non-state actors (as they did for the success of the urban poor like the Self-Employed Women's Association in Gujarat or the Working Women's Forum in Tamil Nadu) play an essential role in enabling groups of poor women to become effective agents of development. Microfinance is only a tool and an enabling element; micro-finance could go only so far in fighting rural poverty and could be useful only if it allows the poor to become more productive in creating wealth under favorable conditions.

Wrenn (2007) in article "Perceptions of the Impact of Microinance on Livelihood security" advocated for much wider impact assessments of microfinance projects, other than financial impact, if the true impact of microfinance is to be understood. They argued that instead of using traditional financial impact assessments, assessments should be broadened to include social, cultural and political impacts on clients, their families and indeed the wider community. The role of microfinance in poverty alleviation is subsequently being underrated by not assessing the wider impacts of microfinance interventions, even though positive impacts are clearly taking place.

Khatiwada (2017) analyzed "Impact of Micro-Finance on Poverty Alleviation in Nepal" and states micro- 
Microfinance Intervention and Livelihood Status: (With References to Gramin Bikash Bank Limited)

finance is certainly not a medicine for poverty; it has proved itself as a useful tool to fight against poverty. It has provided important contribution in the country like Nepal, Bangladesh and Malaysia but it is not fruitful in the most undeveloped countries of Africa. In Nepal, development of micro-finance has improved the living standard of her rural people. Impact analysis of micro-finance suggests that the majority of borrowers who already have some assets (or business skills and education) are more likely to succeed through MF intervention. Financial system approach and poverty lending approach both are beneficial for the poor. Upadhyay (2015) stressed on objective of identify the efficacy of Micro Finance in women empowerment and to explore the ramifications of awareness and socioeconomic alterations owing to Micro Finance program. Both quantitative and qualitative data from primary and secondary sources were used in the study. Microfinance program has supported to women's income generating and livelihood activities and helped in poverty reduction owing to which rural women's life style and way of living is altering. Gender empowerment through Micro Finance incorporates emancipation and empowerment of women without creating a misgiving of emasculation of men. Emancipation of women is procuring economic, social and political rights and equality meant for fostering a balance in gender relations as against the one-sided women empowerment approach.

Adhikari \& Shrestha (2013) found that the concept of micro-credit was developed to mobilize small savings of poor people to create deposit, which may be accessible to unreachable and un-bankable poor, especially women. The study has highlighted that microfinance is an effective tool for bringing positive impact on the economic status of the respondents along with their family members. It has helped to generate extra income for their family and their own use. The extra income allows the respondents family to buy nutritious food, access to modern health care services and they can afford to send their children to the school.

Sharma (2003) in his article "Microfinance Against Poverty :The Nepalese Scenario" attempted to analyze the extent of the access provided, and the generation of employment opportunities, by the formal and semi-formal microfinance institutions/ programs in addition to identifying the problems faced in attaining financial sustainability by them. In view of the increasing need for microfinance services in terms of both the amount and coverage, NRB needs to enhance its capabilities to regulate, supervise and monitor large number of MFIs and also come up with innovative and suitable credit policies/regulations that would create an enabling environment for MFIs to grow and attain sound financial health. Some of the desired roles for government are demonstrating firm commitment towards poverty alleviation through action, stopping direct involvement in running and managing MFIs, stopping owning MFIs, and handing over presently owned shares of such institutions to the private sector through appropriate and transparent mechanism.

\section{Research Design and Methodology}

Researchers used 'Interventional Research Design' in this research to find the impact of Nepal Grameen Bikash Bank Ltd in livelihood status of the rural area of Pokhara Leknath Metropolitan City. The study is based on randomized control trail (RCT) method. The survey includes 60 micro-finance clients and 60 nonmicro-finance clients living in the same geographical area having similar background and characteristics, have been taken for the study to compare the impact of intervention and non-interventional. The respondent 
Microfinance Intervention and Livelihood Status: (With References to Gramin Bikash Bank Limited)

for data collection has been taken from Lamachaur, Pumdi-Bhumdi, Bhalam, Puranchaur, Vurjung-Khola and Chitepani. Strafied sampling technique has been used for selection of respondents. The study is mainly based on primary data. Researchers had been visited in different groups and centers of NGBBL and reliable set of questionnaire was distributed in rural area of Pokhara Leknath Metropolitan city and its periphery. . To find cluster of interventional group in rural area secondary data is used. . For the analysis various statistical were used and the significant help of MS - EXCEL, SPSS is taken for the calculation and analysis of data. Both parametric test (Independent sample t- test and regression analysis), non-parametric test (Chi-square test) method can be applied to evaluate the impact of MF intervention on livelihood improvement.

\section{Result and Discussion}

This section is aimed to display and evaluate the collected data regarding the objectives. The main component of micro-finance program for rural women is to provide loan for women especially in income generation and enhance living standard as well as livelihood status of interventional people. It consists of household analysis in term of family income, consumption expenses, capital expenditure, occupational status and social informational awareness.

\subsection{Descriptive Analysis}

Table1. Marital Status of Respondent

\begin{tabular}{|l|l|l|l|}
\hline Marital status & Micro finance intervened & Micro finance non-intervened & Total \\
\hline Married & $88.30 \%$ & $98.30 \%$ & $93.30 \%$ \\
\hline Widow & $11.70 \%$ & $1.70 \%$ & $6.70 \%$ \\
\hline Total & $100.00 \%$ & $100.00 \%$ & $100.00 \%$ \\
\hline
\end{tabular}

Source: Field Survey, 2017.

Above table shows that majority $93.3 \%$ of the member surveyed was married and widow was $6.7 \%$. This shows that married women are participatory in nature in comparison to widow. Micro finance focused on widow which is seen from the above table.

Table 2: Demographic Feature of Respondent

\begin{tabular}{|l|l|l|l|l|l|}
\hline Features & N & Minimum & Maximum & Mean & Std. Deviation \\
\hline No of children of Respondent & 120 & 0 & 4 & 2.15 & 0.774 \\
\hline Age of Respondent & 120 & 20 & 72 & 38.86 & 11.168 \\
\hline Family Size of Respondent & 120 & 2 & 10 & 4.99 & 1.387 \\
\hline Intervened Respondent & \multicolumn{5}{l|}{} \\
\hline No of children of Respondent & 60 & 0 & 4 & 2.17 & 0.74 \\
\hline Age of Respondent & 60 & 20 & 70 & 41 & 10.567 \\
\hline Family Size of Respondent & 60 & 2 & 10 & 5.1 & 1.515 \\
\hline Non intervened Respondent & \multicolumn{5}{|l|}{} \\
\hline No of children of Respondent & 60 & 1 & 4 & 2.13 & 0.812 \\
\hline Age of Respondent & 60 & 24 & 72 & 36.72 & 11.427 \\
\hline Family Size of Respondent & 60 & 2 & 8 & 4.88 & 1.25 \\
\hline
\end{tabular}

Source: Field Survey, 2017. 
Microfinance Intervention and Livelihood Status: (With References to Gramin Bikash Bank Limited)

In above data set average age of respondent, family size and number of children was 38.86 years, 4.99 people and 2.15 children respectively. The youngest respondent was 20 and oldest was 72 years old.

Table 3: Educational Level of Respondent

\begin{tabular}{|l|l|l|l|}
\hline Education Level & Intervented (\%) & non-intervented & Total \\
\hline Illiterate & $3.30 \%$ & $11.70 \%$ & $7.50 \%$ \\
\hline literate but not Formal Education & $53.30 \%$ & $55.00 \%$ & $54.20 \%$ \\
\hline Under SLC & $30.00 \%$ & $13.30 \%$ & $21.70 \%$ \\
\hline SLC & $10.00 \%$ & $13.30 \%$ & $11.70 \%$ \\
\hline Intermediate and Above & $3.30 \%$ & $6.70 \%$ & $5.00 \%$ \\
\hline Total & $100.00 \%$ & $100.00 \%$ & $100.00 \%$ \\
\hline
\end{tabular}

Source: Field Survey, 2017.

Above table shows those majorities of respondent was literate but not gained formal education. 54.2\% respondent was literate but not gain formal education, 21.70\% was under SLC, 7.5\% was illiterate, and 11.7\% was SLC level and $5.00 \%$ of respondent gained intermediate and above education. Above data and figure reflect that there was no significant difference in education level of respondents in between interventional and non- interventional group.

Table 4: Interventional Effect on Occupational Status

\begin{tabular}{|l|l|l|}
\hline Status & Intervention (\%) & Non intervention (\%) \\
\hline Modern & 70.00 & 35.00 \\
\hline Traditional & 30.00 & 65.00 \\
\hline Total & 100.00 & 100.00 \\
\hline
\end{tabular}

Source: Field Survey, 2017.

Table shows that interventional population was significantly involved in modern occupation. Here modern occupation involves professional agriculture farming, professional livestock, poultry farming, small business, service/ job and foreign employment. Similarly, traditional occupation involves traditional crops production, unmanaged livestock and wages based labor work.

Table. 5: Educational Effect on Occupational Status

\begin{tabular}{|l|l|l|l|}
\hline Educational Level & Modern & Traditional & Total \\
\hline Illiterate & 2.00 & 7.00 & 9.00 \\
\hline Not Formal Education & 30.00 & 35.00 & 65.00 \\
\hline Under SLC & 15.00 & 11.00 & 26.00 \\
\hline SLC & 3.00 & 1.00 & 4.00 \\
\hline Intermediate and Above & 3.00 & 3.00 & 6.00 \\
\hline Total & 63.00 & 57.00 & 120.00 \\
\hline
\end{tabular}

Source: Field Survey, 2017.

From above table, it shows educational status of respondent effect on occupational status. Those acquiring academic education were largely involve in modern occupation but for those below formal education have no significant different on selecting occupation. Among 65 literate without formal education 30 involve in modern and 35 in traditional. Similarly, among 26 under SLC respondent 15 involve in modern and 11 in traditional occupation. Among 4 above SLC respondent 3 involve in modern occupation while 1 in traditional occupation. 
Microfinance Intervention and Livelihood Status: (With References to Gramin Bikash Bank Limited)

\subsection{Descriptive Analysis of Livelihood Parameters}

In this heading income and expenses of house hold was measured by using mean as prime parameter and standard deviation shows deviation among each group. Income of household, consumption expenses, saving was measured in monthly basis and capital expenses was measured in annual basis.

Table 6: Descriptive Analysis of Livelihood Parameters

\begin{tabular}{|l|l|l|l|l|l|}
\hline $\begin{array}{c}\text { Interventional } \\
\text { Status }\end{array}$ & \multicolumn{1}{|c|}{$\begin{array}{c}\text { Statistical } \\
\text { Tools }\end{array}$} & $\begin{array}{c}\text { Monthly } \\
\text { Income }\end{array}$ & $\begin{array}{c}\text { Monthly Consumption } \\
\text { Expenses }\end{array}$ & $\begin{array}{c}\text { Annual Capital } \\
\text { Expenditure }\end{array}$ & $\begin{array}{c}\text { Monthly } \\
\text { Savings }\end{array}$ \\
\hline Intervention & Mean & 41733.33 & 18391.67 & 128866.67 & 16400.0 \\
\hline & Number & 60.00 & 60.00 & 60.00 & 60.00 \\
\hline & S.D & 20856.95 & 7746.421 & 107756.54 & 13977.2 \\
\hline Non-Intervention & Mean & 28200 & 14550.00 & 83050 & 8625 \\
\hline & Number & 60.00 & 60.00 & 60.00 & 60.00 \\
\hline & S.D & 17100.69 & 6026.565 & 72528.294 & 11954.6 \\
\hline Total & Mean & 34966.67 & 16470.83 & 105958.33 & 12512.5 \\
\hline & Number & 120.00 & 120.00 & 120.00 & 120.00 \\
\hline & S. D & 20170.25 & 7158.85 & 94309.2 & 13526.2 \\
\hline
\end{tabular}

Source: Field Survey, 2017.

Table shows that on an average the respondents have saving in some amount. In above table it shows the separate condition of consumption, income, capital expenses and saving in control group and experimental group. Average monthly income of microfinance intervened people was significantly higher than non intervention people. In consumption expenses there was less difference between interventional and non interventional group and significant difference in capital expenditure, income and saving.

Table 7: Sources of Loan Taken

\begin{tabular}{|l|l|l|l|}
\hline Source of Loan & Intervention & Non- Intervention & Total \\
\hline MFIs & 55.00 & 0.00 & 55.00 \\
\hline Bank & 2.00 & 7.00 & 9.00 \\
\hline Relatives & 0.00 & 20.00 & 20.00 \\
\hline Friends & 0.00 & 9.00 & 9.00 \\
\hline Total & 57.00 & 36.00 & 93.00 \\
\hline
\end{tabular}

Source: Field Survey, 2017.

Since the research is based on rural areas, people mostly take loan from microfinance institutions being the member of NGBBL. 50 among the members of NGBBL have taken loan.

Table 8: Business Creation

\begin{tabular}{|l|l|l|}
\hline \multicolumn{1}{|c|}{ Micro Business } & \multicolumn{1}{c|}{ Intervention (\%) } & Non- Intervention (\%) \\
\hline Created & 58.33 & 18.33 \\
\hline Non- Created & 41.67 & 81.67 \\
\hline Total & 100.00 & 100.00 \\
\hline
\end{tabular}

Source: Field Survey, 2017. 
Microfinance Intervention and Livelihood Status: (With References to Gramin Bikash Bank Limited)

From above table, it shows that around half of the microfinance intervention people were facilitated for creating micro-business. But, only $18 \%$ respondents on 60 non-intervention, creating micro-business. This result shows that the financial support of NGBBL helps to create small business.

\subsection{Inferential Analysis and Discussion}

Table 9: Chi-square Test with Different Variables

\begin{tabular}{|l|l|l|l|}
\hline Variable & Chi square value & P value & Cramer's V \\
\hline Education & 7.592 & 0.108 & 0.252 \\
\hline Occupational status & 14.737 & 0.000 & 0.350 \\
\hline Micro enterprise creation & 21.244 & 0.000 & 0.421 \\
\hline Loan taken & 29.405 & 0.000 & 0.495 \\
\hline Occupation change & 69.474 & 0.000 & 0.761 \\
\hline
\end{tabular}

Source: Field Survey, 2017.

Above table shows there was no association between micro finance intervention and education of respondents. But there was association between occupational status, microenterprise creation, loan taken and occupational status change. It means respondent involved in microfinance also involve in modern occupation, create micro enterprises, able to take more loan and change old traditional occupation. The cramer's V of occupational change is highest among all which shows that there was high association between occupational change and microfinance intervention

Table 10: Independent Sample T Test with Different Variables

\begin{tabular}{|l|l|l|}
\hline Variable & T value & p value \\
\hline Monthly income & 3.887 & 0.000 \\
\hline Consumption expenditure & 3.039 & 0.003 \\
\hline Capital expenditure & 2.732 & 0.007 \\
\hline Monthly saving & 3.274 & 0.001 \\
\hline
\end{tabular}

Source: Field Survey, 2017.

Above table shows microfinance intervention increases income, Consumption expenditure, capital expenditure and monthly saving of the people at 5\% significance level. It means mean monthly income, Consumption expenditure, capital expenditure and monthly saving of intervention people is higher than non- intervention people.

Consumption expenses include various expenses as food, cloth, health, education, entertainment, utilities etc. Increase in consumption expenses means they spent more on their basic needs and on development parameters. This shows microfinance intervention has increased the livelihood status of the people.

Capital expenditure includes those expenses which are occurring on acquiring long term goods. In this section researcher collected data of capital expenses for land, house accessories, appliances, and furniture. Expenses on capital item reflect that they fulfill their basic need for living and tend towards betterment of life. Intervention people have higher capital expenses means they spent more on commodities and assets to make their life easy. This shows microfinance intervention increased the livelihood status of the people. 
Microfinance Intervention and Livelihood Status: (With References to Gramin Bikash Bank Limited)

\subsection{Regression Analysis}

Regression Analysis is used to determine the significance between the dependent and independent variables. Here the research is confined to livelihood status as dependent variable whereas occupational status, income level, capital expenditure, consumption expenditure and information access. The regression analysis is presented below.

Table 11 - Regression Analysis for Dependent and Independent Variables

\begin{tabular}{|c|c|c|c|c|c|}
\hline \multicolumn{6}{|c|}{ Regression Analysis for dependent and independent variables } \\
\hline & Sum of Squares & Df & Mean Square & $\mathbf{F}$ & Sig. \\
\hline Regression & 17.44229084 & 5 & 3.4884 & 16.1697 & $.000^{\mathrm{b}}$ \\
\hline Residual & 7.55093409 & 35 & 0.2157 & & \\
\hline Total & 24.99322493 & 40 & & & \\
\hline \multicolumn{6}{|c|}{ Regression Analysis of variables for interventional group } \\
\hline & \multicolumn{2}{|c|}{ Sum of Squares } & Df & $\mathbf{F}$ & Sig. \\
\hline Regression & \multicolumn{2}{|c|}{2.754} & 5 & 5.445 & $.002^{\mathrm{b}}$ \\
\hline Residual & \multicolumn{2}{|c|}{2.327} & 23 & & \\
\hline Total & \multicolumn{2}{|c|}{5.082} & 28 & & \\
\hline \multicolumn{6}{|c|}{ Regression Analysis of variables for non interventional group } \\
\hline & Sum of Squares & df & Mean Square & $\mathbf{F}$ & Sig. \\
\hline Regression & 1.015653315 & 5 & 0.20313 & 1.89914 & $.229^{b}$ \\
\hline Residual & 0.641754092 & 6 & 0.10696 & & \\
\hline Total & 1.657407407 & 11 & & & \\
\hline
\end{tabular}

From the table above the overall significance is 0.00 which means the acceptance of impact of independent variables on dependent one. We can conclude that capital expenditure, consumption expenditure, income level, information access and occupation status create an impact on livelihood status of the people. In case of interventional group, we observed that the dependent variable is affected by independent variable. T value is 0.002 which is lower than 0.05 . This implies that livelihood status is dependent to occupational status, income level, information access, consumption pattern and capital expenditure made. From regression analysis of the intervened group the members of microfinance has been enjoying the uplift of livelihood status. Talking about the non interventional group, T value is 0.229 which is higher than 0.05 . This implies that livelihood status is not dependent to the independent variables in case of non interventional group. Occupational status, income, capital expenditure, consumption expenditure and information access are not much uplifted among non members in rural areas in comparison to members.

\section{Conclusion}

Micro finance is a tool of increasing livelihood status of marginalized people. The study shows that married women were more participative in NGBBL. The size of family and number of children has no significant effect on microfinance involvement. The majority of respondent was literate but not gained any formal 
Microfinance Intervention and Livelihood Status: (With References to Gramin Bikash Bank Limited)

education. It is found that the interventional people are approximately double in number while comparison with non- interventional group regarding modern occupation. Those acquiring higher education were involved in modern occupation and respondents of under SLC level were approximately equal in both occupational status. It was analyzed that most of the rural people in Pokhara were involved in traditional agriculture; among them non-interventional people were in large number. In addition, major occupation of NGBBL members was small business, foreign employment and managed agriculture but in case of non member result will be drastically low. The study reveals that NGBBL provides various non financial services like small business training, women empowerment and vocational training in addition to financial services. Based on priority given by the respondents, research shows that; interventional respondent use micro credit for agricultural, livestock and small business purpose respectively. But, in case of non-interventional group main purpose of taking loan was household consumption. This implies microcredit is useful on creating micro business which ultimately generates income and this uplifts livelihood status of people.

People in rural areas have a perception of traditional money saving and mobilizing technique in microfinance. The women in groups are unaware of the social benefits that they can enjoy through social welfare, women empowerment and awareness. The groups need to be active for health issues in society which creates upliftment of living standard. The cultural aspects have been on dark side. Microfinance intervention needs to highlight these aspects. Microfinance intervention must be focused on political, social and cultural aspects in order to uplift the living standard. Looking at the overall prospect in current scenario, microfinance intervention has somewhat created a positive impact on livelihood status of the people in rural area.

\section{References:}

Agrawal, B. (2009). Gender and forest conservation: The impact of women's participation in community forest governance. Ecological Economics, 2785-2799

Christen, R. P. (1995). Maximizing the Outreach of Microenterprise Finance: An Analysis of Successful Microfinance Programs. Washington, D.C.: Agency for International Development.

National Planning Commission, (2016). 14th Interim Plan. National Planning Commission. Retrieved October 20, 2016, http://www.npc.gov.np

Ayodeji, E.A. (2011). Can Microfinancing Improve Small and Medium Scale Enterprises in Lagos State, Nigeria. IOSR Journal of Economics and Finance.

Chambers, R. \& Conway, G.R. (1992). Sustainable Rural Livelihoods: Concepts for the 21st Century. Institute of Development Studies (IDS) Discussion Paper, 296.

Helms, B. (2006). Access for all: Building Inclusive Financial System. Small Entreprise Development, 23.

Mutua, K., Nataradol, P., Otero, M., \& Chung, B. (1996). The view from the field: Perspectives from managers of microfinance institutions. Journal of International Development.

Ray, S. (2008). Alleviating poverty through micro-finance: SGSY experience in Orissa. Sociological Bulletin, 211-239.

RMDC. (2009). State of Microfinance in Nepal. 
Microfinance Intervention and Livelihood Status: (With References to Gramin Bikash Bank Limited)

Sharma, S.R. (2003). Microfinance Against Poverty : The Nepalese Scenario. Economic Review: occasional Paper.

Sharma, S. R. (2003). An Emperical overview of micro entreprises and micrifinance development in Nepal. Journal of Nepalese Business Studies. 3-12.

Shrestha, J.; Bhandari, D. (2013). Economic impact of micro finance in Nepal: A Case study of Manamaiju Village Development Committee. Economic Journal of Development Issues.

UNDP. (2006). International Year of Micro Credit. United Nations Development Program.

Upadhyay, P. (2015). Hierarchical to gender egalitraianism: Women empowerment and emancipation through micro finance in rural Nepal. The Journal of Nepalese Business Studies. 48-62

Woller, J.C. (2004). Microfinance: A Comprehensive Review of the existing literature. Journal of Entrepreneurial Finance.

Wrenn, E. (2007). Perception of the impact of microfinance on livelihood security. Research and Perspectives on Development Practice. 